\title{
STUDIES ON THE MOSAIC OF PEPPERS (CAPSICUM FRUTESCENS) IN PUERTO RICO०
}

\author{
By Arturo Rogue aNd José Adsuar
}

\section{INTRODUCTION}

A mosaic disease of peppers causing stuntiness of the plant and severe malformation of the fruit appeared in epidemic form about three years ago in the Agricultural Experiment Sub-station at Isabela. Since then it has spread with great rapidity and intensity throughout that region and has also been found causing serious damage in other important vegetable sections of the island. Serrano and Riollano (6) estimated the crop losses due to mosaic for Isabela from 50 to 60 percent in the season of 1938 and stated that further plantings were, in their opinion, a risky proposition.

The first report of pepper mosaic in Puerto Rico known to the writers is that made by Cook (2) in 1927-28. Since then, no effort has been made to study the disease and to determine the virus or viruses involved.

In connection with a breeding program to develop a commercial variety of peppers resistant to mosaic, studies to determine the prevalence, distribution, properties of the virus and varietal susceptibility were undertaken. The experiments were conducted in the Agricultural Experiment Station at Rio Piedras during the years 1939-41.

\section{Materials and Methods}

All plants used for inoculation purposes were grown in sterilized compost soil in 5 inch pots. The plants were kept in a section of the greenhouse screened with 24-mesh copper wire. As an additional precautionary measure the plants were periodically sprayed to prevent, as far as possible, accidental infections due to insect vectors. Inoculations were made when the plants had developed 3 or 4 pairs of leaves and were actively growing. Although the ordinary methods of mechanical transmission were found satisfactory, the brush method was developed and adopted for its practicability. This method consists in the use of a flat artist brush (Mikado No. 5) with bristles cut to a length of about $1 / 2$ inch. The brushes can be used over and over again after sterilization 
in boiling water for fifteen minutes or more and are very convenient for large scale inoculations. Inoculations were performed by gently rubbing the upper surface of two or three of the youngest leaves with a brush that had been dipped in the extract.

The inocultum was obtained by crushing infected leaves in a sterile mortar with sterile sand and water. The resulting macerate was strained through cheese cloth and used without further treatment.

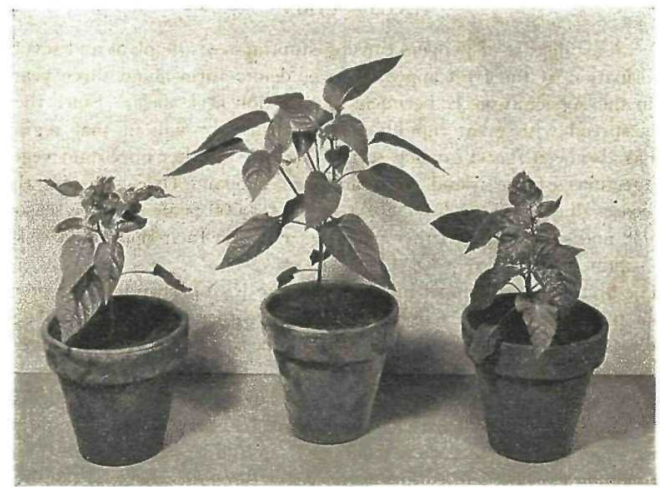

Fic. 1. Young pepper plants of the variety King of the North showing symptoms of pepper mosaic. Plants at left and right inoculated; middle plant, check. Note stunting, mottling and malformation of infected plants.

The longevity "in vitro" was determined by aging the extract in stoppered test tubes for the desired length of time. The thermal inactivation point was determined by immersing $5 \mathrm{cc}$. of the extract in thin walled test tubes in a water bath.

Pure cultures of the viruses, for inoculation and other studies, have. been kept in young pepper and tobacco plants grown in cages. The potato mottle virus (ring spot strain) and the potato vein banding virus were kindly supplied by Prof. J. Johnson of Wisconsin University. The ordinary tobacco mosaic virus and the cucumber mosaic virus were obtained locally from infected tobacco and cucumber plants. 
The commercial varieties of peppers California Wonder and Large Bell Hot, the variety Mirasol (a South American hot pepper) and Nicotiana glutinosa were used as differential hosts in these studies.

All inoculations were repeated at least three times in lots of ten plants.

The insect transmission studies were conducted by subnitting healthy pepper plants grown free from insects to the attack of aphids feeding on plants inoculated with the pepper mosaic virus.

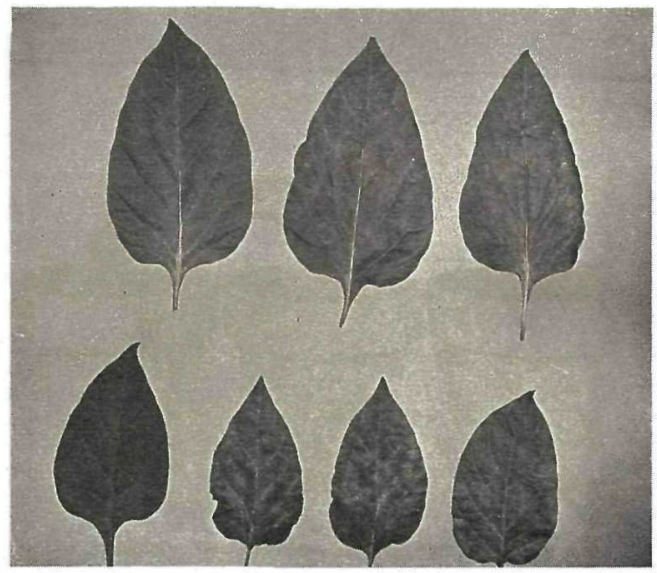

FIG. 2. Infected leaves of two varieties of pepper showing characteristic symptoms of pepper mosaic. Upper and lower left leaves uninoculated. Note veinclearing, mottling and vein-banding.

The immunological relationship between the pepper mosaic virus and other viruses was determined by inoculating the Large Bell Hot variety with the following: Solanum 1 and 2, ordinary tobacco mosaic and cucumber mosaic viruses. After symptoms appeared, the affected plants were reinoculated with the pepper mosaic virus. 


\section{SумртомS}

All susceptible varieties of pepper studied with the exception of the Large Bell Hot, present the following symptoms when infected with the virus causing mosaic: in about 10-12 days after inoculation a marked clearing of the veins develops in the upper younger leaves, followed later by a systemic mottling which, in a majority of cases, ends in a definite vein banding. This last symptom is very characteristic of the mosaic produced by this virus and helps to identify it in the field. In addition

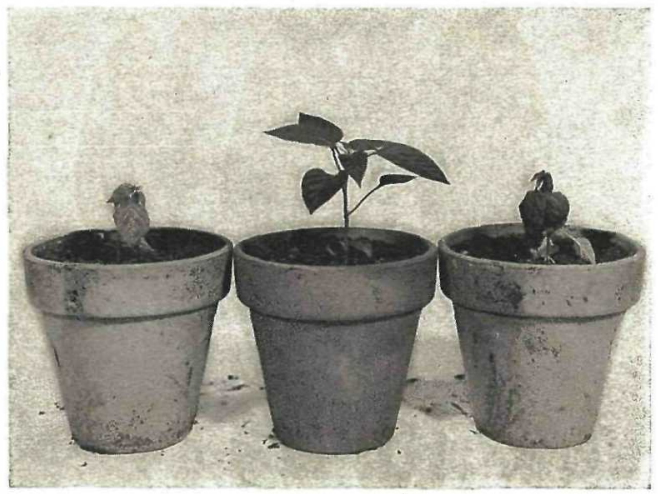

FIG. 3. Young pepper plants of the Large Bell Hot variety inoculated with pepper mosaic virus. Left and right plants inoculated; middle plant, check. Note systemic vein necrosis and leaf shedding.

to the mottling, the leaves become wrinkled and the whole plant is stunted, especially if the infection has taken place early in the development of the plant. Fruit setting is curtailed and those that develop after the symptoms have appeared are undersized, mottled and badly distorted.

The severity of the disease bears a relation to the age of the plants at the time of inoctlation-young plants are more seriously and rapidly affected than old plants.

The variety Large Bell Hot is a hot pepper of medium, square shaped fruits. In young, actively growing plants of this variety the virus pro- 
duces a systemic vein necrosis in from 5-6 days, followed by defoliation, stem streaking and death of the entire plant. These symptoms develop more slowly in the old plants. The characteristic mottling and vein banding do not develop. As no other variety so far studied reacts in this way to this virus, it serves as an excellent host for identification purposes as well as for other studies.

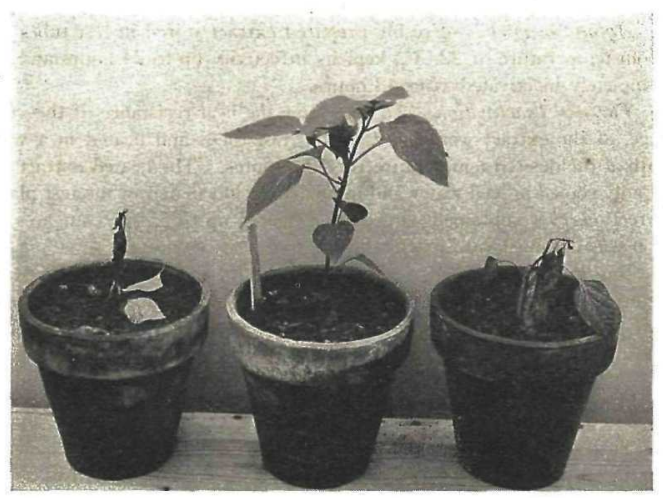

FIG. 4. Young pepper plants of the Large Bell Hot variety inoculated with pepper mosaic virus showing advanced stage of the infection. Left and right plants inoculated; middle plant, check. Note defoliation, stem streaking and death.

\section{Distribution and Prevalence}

The disease is widely spread throughout the island and has been found in almost every place where peppers are grown.

The prevalence of the virus in fields infected with mosaic was determined by sampling at random diseased plants and inoculation into the "Mirasol" variety of pepper. The variety "Mirasol" was used because it reacts with localized necrosis to the Nicotiana virus 1 , thus differentiating between the virus under study and the ordinary tobacco mosaic virus which is widely distributed throughout the island. In seven areas surveyed, its presence ranged from 60 to 95 percent in the plants with mo- 
saic. Tobacco mosaic was found on three of the seven areas and only to an extent of from 1-3 percent of the diseased plants.

\section{Properties of the Virus}

Transmission.-Transmission is easily accomplished by the usual mechanical methods. Evidence of transmission by the aphids Myzus persicae, Sulz., has also been obtained.

Aging "in vitro."-Freshly prepared extract stored in test tubes at a room temperature of $22^{\circ} \mathrm{C}$., kept its infectivity up to 24 hours and was completely inactivated after 48 hours.

Thermal Inactivation.-To determine the heat resistance of the virus, $5 \mathrm{cc}$. of the extract was placed in thin test tubes and heated in a water bath at the desired temperature for 10 minutes. The heated extract was rapidly cooled in iced water and immediately inoculated in the test plants. Infections were obtained with extract heated up to $55^{\circ} \mathrm{C}$., but no reaction was obtained with extract heated to $58^{\circ} \mathrm{C}$. or more.

Dilution.-The effect of dilution on the infectivity of the virus was determined by diluting the fresh extract with sterile water. The dilution end point is low, infectivity begins to fall rapidly at dilutions of 1-80 and infections were only occasionally obtained at dilutions of 1-100.

\section{Immunological ReLationships}

To determine the possible relationship between the virus responsible for the pepper mosaic in Puerto Rico and such common viruses as the tobacco virus 1 , cucumber virus 1 or their strains, and viruses of the Solanum group 1 and 2 which are known to attack peppers in nature, cross inoculation studies were made. The variety of pepper Large Bell Hot, because of its typical systemic vein necrosis reaction was used. Plants reacted as follows when inoculated: chlorosis and mottling with ordinary tobacco mosaic and cucumber viruses, mottling with Solanum virus 1 and localized necrotic spots with Solanum virus 2.

The results demonstrated that the four above mentioned viruses were unable to immunize or protect invaded tissues of the Large Bell Hot pepper against infection by subsequent inoculation with the virus under study.

\section{Host Range}

In an attempt to determine if the virus was limited in its range to the genus Capsicum and at the same time to study its host relationships 
within the Solanaceae, efforts to reproduce the disease in other members of this family were made. Out of eighty-four varieties of the genus Capsicum, including commercial and non-commercial varieties, only two have been found resistant to the virus. A strain of pepper developed by Dr. F. O. Holmes* which reacts with localized necrotic spots when inoculated with the tobacco mosaic virus, reacts with systemic mottling to the Puerto Rico pepper mosaic virus. Among related genera, Nicotiana glutinosa, N. Tabacum, var. Virginia, N. Bigelovii, var. multivalvis, $N$. Bigelovii var. quadrivalvis and N. rustica, developed symptoms when inoculated with the new virus (See Table I). Solamum melongena var.

TABLE I. Symploms developed on different hosts by the Puerto Rico pepper mosaic virus when inoculated artificially

\begin{tabular}{|c|c|}
\hline новт & SYMPTOMS \\
\hline Capsicum frutescens, var. Large Bell Hot & $\begin{array}{l}\text { Vein clearing, systemic vein necrosis, } \\
\text { defoliation, stem streak, death }\end{array}$ \\
\hline C. frutescens, var. California Wonder & $\begin{array}{l}\text { Vein clearing, mottling, vein banding, } \\
\text { stuntiness }\end{array}$ \\
\hline Nicotiana glulinosa & Chlorosis, vein clearing, mottling \\
\hline N. Tabacum, var. Virginia & $\begin{array}{l}\text { Vein clearing, chlorotic spots, vein } \\
\text { banding }\end{array}$ \\
\hline N. Bigelovii, var. multivalvis & Vein clearing, ring spots \\
\hline N. Bigelovii, var. quadrivalvis & Vein clearing, ring spots \\
\hline N. rustica & Vein clearing, mottling, vein banding \\
\hline
\end{tabular}

Puerto Rican Beauty and Lycopersicum esculentum, var. Marglobe, occasionally developed symptoms, but failed to indicate the presence of the virus when tested back to a differential host like the Large Bell Hot pepper. Solanum tuberosum, S. nodiflorum, Datura stramonium, $N$. sylvestris, and $N$. repanda failed to develop symptoms when inoculated. Cucumis sativus, Phaseolus vulgaris and Phaseolus lunatus did not react to the virus.

\section{Discussion}

The nature of the virus causing pepper mosaic in Puerto Rico is not known. A study of the literature dealing with pepper mosaic reveals that several viruses are capable of infecting the genus Capsicum in nature.

* Seed of this strain, a semi-commercial variety of peppers, was kindly supplied by F. O. Holmes of the Rockefeller Institute for Medical Research, Princeton, N. J. 
J. Johnson (5) described eight out of eleven viruses studied as causing definite symptoms in peppers. Blodgett (1) was able to produce a serious disease of peppers by inoculating with the virus causing mottle in tobacco (Solanum 1). E. M. Johnson (4) found peppers susceptible to eighteen of the viruses attacking tobacco in Kentucky. K. M. Smith (7) listed eight viruses capable of infecting peppers. Holmes (3) recorded twelve pathogenic viruses on peppers. A comparison of the properties and symtoms of the viruses causing pepper mosaic elsewhere and the one from Puerto Rico is presented in the following table.

With the possible exception of the potato vein banding virus (virus $Y$ ), the viruses reported differ widely from the Puerto Rico pepper virus not only in physical properties, but in many cases in symptoms as well. The vein banding virus, however, is very similar in physical properties to the virus here reported. The symptomatology, nevertheless, is very different from that produced by our virus. In the Large Bell Hot variety the vein banding virus produces necrotic spots, wrinkleness and blight while the pepper virus produces a distinct systemic vein necrosis which is always fatal. The difference in symptom expression, however, is not sufficient in itself to establish relationship between the viruses.

Plants of the Large Bell Hot variety inoculated with the vein banding virus and showing symptoms were reinoculated with the virus causing pepper mosaic in Puerto Rico. The typical systemic vein necrotic symptoms of this differential host developed, showing that the former virus offered no protection to infection by our virus and, therefore, that the two viruses were not closely related.

As far as the writers know the potato mild mosaic virus (potato virus A) has not been reported attacking peppers. Its physical properties, however, closely resemble those of the pepper virus from Puerto Rico and since the symptoms described on $N$. tabacum are also similar it may be possible that they might be related. Unfortunately, the writers have been unable to obtain a pure culture of this virus for comparative studies.

With the possible exception of the ordinary tobacco mosaic virus, no other virus has been reported causing serious and widespread damage to commercial plantings of peppers. The virus here reported, however, causes a disease of considerable importance in our commercial fields and is widely distributed in Puerto Rico. All commercial varieties of peppers so far tested and a large number of non-commercial, ornamental and hot types are susceptible to this virus. It thus appears, that the virus, 
TABLE II. Symptoms and properties of the viruses reported as capable of infecting peppers

\begin{tabular}{|c|c|c|c|c|c|}
\hline \multirow{2}{*}{ VIRUS } & \multirow{2}{*}{$\begin{array}{l}\text { SYMPTOMS oN } \\
\text { Capsicum frutescens }\end{array}$} & \multicolumn{3}{|c|}{ PHYSICAL PROPERTIES } & \multirow{2}{*}{$\begin{array}{l}\text { INMTUNOLOGICAL } \\
\text { REACTION WITH } \\
\text { PUERTO RICO } \\
\text { PEPPBR MOSAIC } \\
\text { VIRUS }\end{array}$} \\
\hline & & AGING & $\begin{array}{l}\text { THERMAL } \\
\text { DEATH-POINT }\end{array}$ & DILUTION & \\
\hline $\begin{array}{l}\text { Puerto Rico pepper mosaic } \\
\text { virus }\end{array}$ & $\begin{array}{l}\text { Mottling, vein banding, } \\
\text { stuntiness, distortion }\end{array}$ & $24-48$ hrs. & $55^{\circ} \mathrm{C} .-58^{\circ} \mathrm{C}$. & $1-100$ & \\
\hline $\begin{array}{l}\text { Tobacco mosaic virus- } \\
\text { Typical strain }\end{array}$ & $\begin{array}{l}\text { Chlorosis, mottling, necro- } \\
\text { sis, stuntiness }\end{array}$ & Indefinite & $93^{\circ} \mathrm{C}$ & $1-1,000,000$ & Negative \\
\hline $\begin{array}{l}\text { Tobacco mosaic virus-- } \\
\text { Masked symptom strain }\end{array}$ & Mottling & Indefinite & $90^{\circ} \mathrm{C}$. & $1-1,000,000$ & Undetermined \\
\hline $\begin{array}{l}\text { Tobacco Etch virus- } \\
\text { Typical strain }\end{array}$ & $\begin{array}{l}\text { Mottling, chlorosis, stunti- } \\
\text { ness, distortion }\end{array}$ & - & - & 一 & Undetermined \\
\hline $\begin{array}{l}\text { Cucumber mosaic virus- } \\
\text { Typical strain }\end{array}$ & $\begin{array}{l}\text { Malformation, chlorosis, } \\
\text { stuntiness }\end{array}$ & $72-96$ hrs. & $60^{\circ} \mathrm{C} .-70^{\circ} \mathrm{C}$ & $1-10,000$ & Negative \\
\hline $\begin{array}{l}\text { Cucumber mosaic virus- } \\
\text { Southern celery mosaic strain }\end{array}$ & $\begin{array}{l}\text { Mottling, necrosis, stunti- } \\
\text { ness }\end{array}$ & 14 days & $75^{\circ}$ C. $-80^{\circ}$ C. & $1-100,000$ & Undetermined \\
\hline $\begin{array}{l}\text { Cucumber mosaic virus- } \\
\text { Lima bean mosaic strain }\end{array}$ & Stuntiness, chlorotic spots & 8 days & $70^{\circ} \mathrm{C}$. & $1-10,000$ & Undetermined \\
\hline $\begin{array}{l}\text { Cucumber mosaic virus- } \\
\text { Potato vein banding strain }\end{array}$ & $\begin{array}{l}\text { Necrotic spots, wrinkleness, } \\
\text { leaf blight }\end{array}$ & $24-36$ hrs. & $52^{\circ} \mathrm{C}$ & $1-100$ & Negative \\
\hline $\begin{array}{l}\text { Potato mottle virus } \\
\text { Typical strain }\end{array}$ & $\begin{array}{l}\text { Chlorotic spots, necrosis } \\
\text { defoliation }\end{array}$ & Over 28 days & $70^{\circ} \mathrm{C}$. & $1-100,000$ & Undetermined \\
\hline $\begin{array}{l}\text { Potato mottle virus- } \\
\text { Potato ring spot strain }\end{array}$ & Systemic necrosis & Over 28 days & $68^{\circ} \mathrm{C}$. & $1-10,000$ & Negative \\
\hline $\begin{array}{l}\text { Potato mottle virus- } \\
\text { Masked mottle strain }\end{array}$ & Systemic necrosis & $一$ & - & - & Undetermined \\
\hline Potato Aucuba mosaic virus & $\begin{array}{l}\text { Chlorotic spots, mottling } \\
\text { distortion, leaf drop }\end{array}$ & $\begin{array}{l}\text { Less than } 4 \\
\text { days at } \\
15^{\circ} \mathrm{C} \text {. }\end{array}$ & $65^{\circ} \mathrm{C}$. & $1-200$ & Undetermined \\
\hline $\begin{array}{l}\text { Tomato spotted wilt virus } \\
\text { Typical strain }\end{array}$ & & $\begin{array}{l}\text { Less than } 5 \\
\text { hrs. }\end{array}$ & $42^{\circ} \mathrm{C}$. & $1-100,000$ & Undetermined \\
\hline Tomato streak virus & Mottling, chlorosis & Indefinite & $85^{\circ} \mathrm{C} .-90^{\circ} \mathrm{C}$. & 一 & Undetermined \\
\hline Tomato ring mosaic virus & $\begin{array}{l}\text { Chlorotic rings, distortion, } \\
\text { stuntiness }\end{array}$ & - & $80^{\circ} \mathrm{C}$ & 一 & Undetermined \\
\hline $\begin{array}{l}\text { Tomato bunchy top virus } \\
\text { Sugar Beet curly - top virus }\end{array}$ & $\begin{array}{l}\text { Symptomless carrier } \\
\text { Vein clearing, curling }\end{array}$ & $\begin{array}{l}12-24 \text { days } \\
\text { Over } 7 \text { days }\end{array}$ & $\begin{array}{l}70^{\circ} \mathrm{C} . \\
75^{\circ} \mathrm{C}-80^{\circ} \mathrm{C} .\end{array}$ & $\overline{1-1,000}$ & $\begin{array}{l}\text { Undetermined } \\
\text { Undetermined }\end{array}$ \\
\hline
\end{tabular}


although successfully transmitted to other members of the Solanaceae, is largely confined to the genus Capsicum in Puerto Rico.

Based on a survey of the literature available and the evidence presented, the virus under discussion may be some described form thus far not reported attacking peppers, or an entirely undescribed entity.

\section{SUMmary}

A serious mosaic disease of peppers in Puerto Rico is reported. The disease is widely spread throughout the island and causes mottling of the foliage, stuntiness of plant and malformation of the fruit.

The virus responsible for the disease is easily transmitted mechanically. Evidence of transmission by the aphid Myzus persicae has been obtained. The virus is inactivated "in vitro" after 48 hours. The thermal inactivation point ranges from $55^{\circ}$ to $58^{\circ} \mathrm{C}$. Infectivity falls rapidly at dilutions of $1: 80$ and infections are only occasionally obtained at dilutions of $1: 100$.

No immunological relationship was found between the virus causing mosaic of peppers in Puerto Rico and the potato mottle virus (ring spot strain), the potato vein banding virus, the ordinary tobacco mosaic virus and the cucumber mosaic virus.

Out of eighty-four varieties of peppers studied only two were found resistant to the virus. Nicotiana tabacum, $N$. glutinosa, N. Bigelovii var. multivalvis, N. Bigelovii var. quadrivalvis, and $N$. rustica reacted when inoculated with the virus. Solanum nodiflorum, $S$. tuberosum, Datura stramonium, Nicotiana repanda and $N$. sylvestris failed to develop symptoms when inoculated. Cucumis sativus, Phaseolus vulgaris and $P$. lunatus did not react to the virus.

The studies suggest that the virus causing pepper mosaic in Puerto Rico is either a described form thus far not reported attacking peppers, or an undescribed entity.

\section{LITERATURE CITED}

1. Blodgett, F. M. A potato virus on peppers. Phytopath. 17: 775-782, 1936.

2. Cook, M. T. In Annual Report Ins. Expt. Sta., Dept. of Agri. and Labor of Puerto Rico. Fiscal Year 1927-28: 65, 1929.

3. Holmes, F. O. Handbook of phytopathogenic viruses. Burgess Publishing Co. Minneapolis. 221 p., 1939. 
4. Johnson, E. M. Virus diseases of tobacco in Kentucky. Kentucky Agr. Expt. Sta. Res. Bul. 306: 415 p., 1930.

5. Johnson, J. The classification of plant viruses. Agri. Expt. Sta. Univ. Wisconsin Res. Bul. 76, 16 p., 1927.

6. Serrano, L. A. and A. Riollano. Letter. 1938.

7. Smith, K. M. A textbook of plant virus diseases. J. \& A. Churchill Ltd. London, 615 p., 1937. 